\title{
Epidemiological analysis of infection by the bovine viral diarrhea virus on family farms in Brazil
}

\section{Análise epidemiológica da infecção pelo vírus da diarreia viral bovina em rebanhos da agricultura familiar, Brasil}

\author{
Marlos José Portela Rêgo'; Antonio Fernando Barbosa Batista Filho²; \\ Pollyanne Raysa Fernandes de Oliveira ${ }^{3}$; Jonas de Melo Borges ${ }^{4}$; \\ Carlos André Barbosa de França ${ }^{5}$; Cláudia Pestana Ribeiro; \\ Edviges Maristela Pituco ${ }^{6}$; José Wilton Pinheiro Junior ${ }^{7 *}$
}

\begin{abstract}
The aim of the present study was to determine the seroprevalence of infection by the bovine viral diarrhea virus (BVDV) on family farms, as well as to study the risk factors associated with the infection. In total, 319 blood serum samples were collected from cattle, of reproductive age ( $>24$ months) in 24 herds from 11 cities of the brejo microregion in Pernambuco. The samples were subjected to the seroneutralization test to detect anti-BVDV antibodies. In order to identify the risk factors associated with the BVDV, a questionnaire epidemiologic was applied and followed by statistical analysis of logistic regression, with the serological test considered as the dependent variable (reagent or non-reagent). A prevalence of $51.1 \%(163 / 319$; C.I. $45.5 \%-56.7 \%)$ was found in the present study. Of the 24 herds sampled, $100.0 \%$ contained at least one reagent animal. The prevalence in the counties ranged from $23.1 \%$ to $70.0 \%$. The following risk factors were identified in the present study: not providing colostrum (OR 3.85; $\mathrm{p}=0.018$ ); disease unknown (OR 2.54; $\mathrm{p}=0.001$ ) and consortium breeding (OR 1.76; $\mathrm{p}=0.013$ ). Based on these results, it was clear that BVDV infection is widespread in herds on family farms in the microregion studied herein. Health education policies must be implemented for producers and professionals who provide technical assistance. In addition, based on the risk factors identified in the present study, hygiene-sanitary measures should be implemented in order to reduce the prevalence of the BVDV.
\end{abstract}

Key words: BVDV. Cattle. Diagnosis. Risk factors.

\section{Resumo}

Objetivou-se com este estudo determinar a soroprevalência e estudar os fatores de risco associados à infecção pelo vírus da diarreia viral bovina (BVDV) nas unidades produtivas de agricultura familiar.

${ }^{1}$ M.e em Sanidade e Reprodução de Ruminantes, Instituto Agronômico de Pernambuco, Recife, PE, Brasil. E-mail: marlosrego@ hotmail.com

${ }^{2}$ Residente em Medicina Veterinária, Universidade Federal Rural de Pernambuco, UFRPE, Recife, PE, Brasil. E-mail: afbbf@, hotmail.com

${ }^{3}$ Discente do Programa de Pós-Graduação em Sanidade e Reprodução de Ruminantes, UFRPE, Garanhuns, PE, Brasil. E-mail: pollyanne_raysa_fernandes@hotmail.com

${ }^{4}$ M.e em Sanidade e Reprodução de Ruminantes, Autônomo, Garanhuns, PE, Brasil. E-mail: jonas borges1@hotmail.com

5 M.e em Sanidade e Reprodução de Ruminantes, Instituto Agronômico de Pernambuco, Recife, PE, Brasil. E-mail: vetandr@, hotmail.com

${ }^{6}$ Pesquisadores, Instituto Biológico, São Paulo, SP, Brasil. E-mail: ribeiro@biologico.sp.gov.br; pituco@biologico.sp.gov.br

${ }^{7}$ Prof., Departamento de Medicina Veterinária, UFRPE, Recife, PE, Brasil. E-mail: wiltonjrufrpe@gmail.com

* Author for correspondence 
Foram coletadas 319 amostras de soro sanguíneo, de bovinos em idade reprodutiva ( $>24$ meses), procedentes de 24 rebanhos bovinos em 11 municípios da microrregião brejo pernambucano. As amostras foram submetidas ao teste de soroneutralização para detecção de anticorpos anti-BVDV. Para a identificação dos fatores de risco associados ao BVDV, foi aplicado um questionário epidemiológico e foi realizada uma análise estatística de regressão logística, considerando como variável dependente o exame sorológico (reagente ou não reagente). Observou-se com este estudo uma prevalência de $51,1 \%$ (163/319; I.C. 45,5\% - 56,7\%). Dos 24 rebanhos amostrados, 100\% apresentaram pelo menos um animal reagente. A prevalência nos municípios variou de $23,1 \%$ a $70,0 \%$. Os fatores de risco identificados neste estudo foram: não fornecer colostro (OR 3,85; $\mathrm{p}=0,018$ ); não conhecer a enfermidade (OR 2,54; $\mathrm{p}=0,001)$ e criação consorciada (OR 1,$76 ; \mathrm{p}=0,013)$. Diante dos resultados obtidos, constatou-se que a infecção pelo BVDV está disseminada nos rebanhos de agricultura familiar na microrregião estudada e que políticas de educação em saúde devem ser implementadas tanto para os produtores como para os profissionais que prestam assistência técnica. Além disso, medidas higiênico-sanitárias com base nos fatores de risco identificados neste estudo devem ser implementadas como forma de reduzir a prevalência do BVDV.

Palavras-chave: Bovinos. BVD. Diagnóstico. Fatores de risco.

\section{Introduction}

As one of the main activities of Brazilian agribusiness, cattle raising plays an important role in both national and international markets. Brazil stands in 2nd place in the ranking of the largest holders of effective herds in the world, with approximately 200 million head of cattle (BRASIL, 2014). According to the agricultural census for family farming, which was conducted by the Brazilian Institute of Geography and Statistics (IBGE 2006a), family farms represent 74.4\% (12.3 million) of the people involved with agriculture in the country (IBGE, 2006a). In addition, they are responsible for $58.0 \%$ of the milk production in Brazil and represent $30.0 \%$ of the national beef cattle market.

The Bovine Viral Diarrhea Virus (BVDV) is considered one of the major pathogens that affect cattle, causing significant economic losses in the supply chain (FLORES et al., 2005). The presence of the BVDV in a herd is associated with a reduction of animal development (GUIMARÃES et al., 2001) and sub-clinical and clinical manifestations of a respiratory, gastrointestinal or immunosuppressive nature. In more, BVDV2, severe cases, mucosal disease (MD) and hemorrhagic syndrome (HS) are common (DIAS; SAMARA, 2003; FLORES et al., 2005). BVDV is also associated with reproductive disorders, such as heat repetition (GÜR, 2011), embryonic mortality (DEZEN et al., 2013), metritis and the retention of placenta (ASMARE et al., 2013). The mild form of the disease is significant, since the animals do not exhibit any clinical signs and consequently, many producers cannot identify the losses to the cattle industry (DIAS; SAMARA, 2010).

In Europe, seroprevalence rates ranging from $32.9 \%$ to $61.6 \%$ were recorded (GÜR, 2011; BEDEKOVIĆ et al., 2013; SARRAZIN et al., 2013). In Africa, a study reported seropositivity of 11.7\% (ASMARE et al., 2013). In South America, seroprevalence rates ranging from $27.1 \%$ to $69.0 \%$ have been recorded in several countries (GUARINO et. al., 2008; CARBONERO et al., 2011; HERRERA et. al., 2011). In Brazil, prevalence rates range from $22.2 \%$ (THOMPSON et al., 2006) to $85.4 \%$ (QUINCOZES et al., 2007). In Pernambuco state, Castro et al. (1993) found a prevalence of $72.6 \%$ $(209 / 288)$ in cattle, using the virus neutralization test. However, no studies have as yet been realized focusing specifically on the BVDV on family farms in Brazil.

The aim of the present study was to analyze the epidemiological aspects associated with infection with bovine viral diarrhea virus on family farms in the brejo microregion of Pernambuco, Brazil. 


\section{Materials and Methods}

This project was approved by the Ethics Committee for Animal Use in the Federal Rural University of Pernambuco under protocol number 057/2014.

We used the epidemiological method for transversal studies (CÔRTES, 1993). In order to determine the prevalence of infection with the bovine viral diarrhea virus, we considered a total of 151,418 cattle (IBGE, 2006b), with an expected prevalence of $72.6 \%$ (CASTRO et al., 1993) for the BVDV, a confidence interval of $95 \%$ and a statistical error of 5\% (THRUSFIELD, 2004). Thus, the minimum number required for a prevalence study was 306 cattle. The number of animals assessed in each herd was calculated using Win Episcope 2.0 software, with the aforementioned parameters. The properties were chosen for convenience, based on the records of the Agronomic Institute of Pernambuco (IPA).

In total, 319 samples were collected from animals of different breeds and aptitudes (beef or dairy). The animals were all of reproductive age ( $>24$ months), but were subjected to different management systems and had no vaccination history. They came from 24 family farms, which were distributed throughout the brejo microregion of Pernambuco in the following counties: Agrestina (47 animals), Altinho (91 animals), Barra de Guabiraba (30 animals), Bonito (15 animals), Camocim de São Félix (26 animals), Cupira (19 animals), Ibirajuba (20 animals), Lagoa dos Gatos (29 animals), Panelas (23 animals), Sairé (9 animals) and São Joaquim do Monte (10 animals) (Figure 1). These counties represent 2.6\% $\left(2.548 .804 \mathrm{~km}^{2}\right)$ of Pernambuco's territory. The total herd in the brejo microregion represents $6.1 \%$ of the total herd of the state (IBGE, 2006b).

Figure 1. Study Area Brejo microregion of Pernambuco.

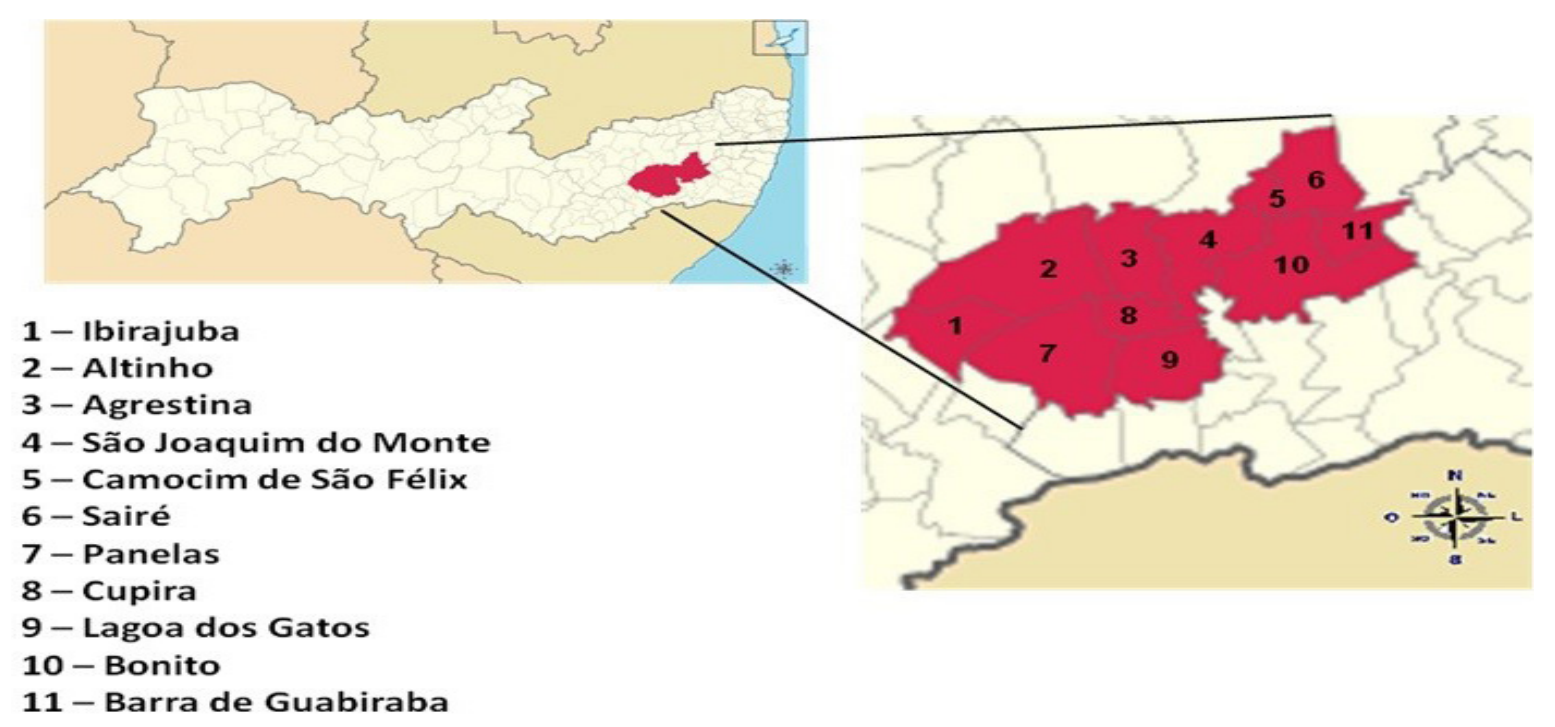

Blood samples were collected by puncturing the median tail vein, after antisepsis using iodinated alcohol, using an amount of $10 \mathrm{~mL}$ in siliconized test tubes without coagulant. The samples were collected between September 2013 and February 2014.
The tubes were labeled and sent to Garanhuns Laboratories Center (CENLAG), Academic Unit of Garanhuns, Federal Rural University of Pernambuco, for due processing. To obtain the serum, the samples were centrifuged at $900 \mathrm{~g}$ for 
10 minutes and the serum obtained was stored in polypropylene microtubes (labeled) and subjected to freezing at $-20^{\circ} \mathrm{C}$ until the serological tests were performed.

During the visits to the properties, an investigative questionnaire was applied, with objective questions about the hygienic-sanitary management of the farm, the reproductive characteristics of the herd, the producers knowledge of the disease, technical assistance and the technological level of the breeding system used. The producers of each property were asked to sign a statement of informed consent and to permit the disclosure of data.

The laboratory test procedure followed the recommendations of the World Organization for Animal Health (OIE), in accordance with the Manual of Diagnostic Test and Vaccines for Terrestrial Animals (OIE, 2012). The samples were submitted to the seroneutralization test to determine the presence of neutralizing antibodies against the BVDV-1, NADL strain. The test sera were subjected to inactivation of complement by incubation in a water bath at a temperature of $56^{\circ}$ $\mathrm{C}$ for 30 minutes. The assay was performed in polystyrene microtiter flat-bottomed 96-well plates (TPP Techno Plastic Products AG®, Switzerland). For the titration of anti BVDV antibodies, the serum samples were diluted in MEM medium in logarithmic base 2 (dilution 1:10 to 1:5.120). Each well of the plate received $50 \mu \mathrm{L}$ of virus solution containing $200 \mathrm{TCID}_{50} / 100 \mu \mathrm{L}$, with the exception of the first column of each plate, which was used for cellular control and did not receive the test serum or virus sample. These columns only received half $100 \mu \mathrm{L}$ of medium Minimum Essential Medium (MEM - Nutricel ${ }^{\circledR}$, Campinas, Brazil).

The serum-virus mixture was incubated for 2 hours in an incubator at $37^{\circ} \mathrm{C}$ with $5 \% \mathrm{CO}_{2}$ and controlled humidity. After incubation, we added $100 \mu \mathrm{L}$ of Madin Darby Bovine Kidney (MDBK) suspension into each well at a concentration of
$3 \times 10^{6}$ cells $/ \mathrm{mL}$. Subsequently, a new incubation was performed for 5 days using an incubator with $5 \% \mathrm{CO}_{2}$ at $37^{\circ} \mathrm{C}$ and controlled humidity.

In each assay, plaque was included to titer the virus once again, which was then used as the control titer for viral suspension. Four dilutions, in ratio ten of the virus (eight replicates per dilution in duplicate) were placed on the plaque, whereas two columns were reserved for cell control. Titer calculation was performed based on the method described by Reed and Muench (1938).

After incubation, a reading test was conducted by monitoring the cytopathic effect (CPE). The sera were considered "non-reactive" when they exhibited antibody titers less than $\log _{10} 1.0$.

Descriptive statistical analysis was performed to determine the absolute and relative prevalence. To analyze the risk factors associated with BVDV infection, univariate analysis of the variables was conducted using the chi-square test, Pearson's test or Fisher's exact test, when necessary. Subsequently, logistic regression analysis was performed, considering the result of the seroneutralization test (reagent or non-reagent) as the dependent variable for BVDV infection. The independent or explanatory variables considered in the model were those that showed a statistical significance $<0.20$. This probability was stipulated so that possible risk factors of the event were not excluded from the analysis. In the final model, risk factor variables with $\mathrm{p}<0.05$ were considered (HOSMER; LEMESHOW, 1989). Epi Info 3.5.1 software was used to perform all statistical calculations.

Prior to preparing the map with the geographic distribution of properties (positive and negative), geographical coordinates were collected from the properties analyzed using GPS equipment and a Universal Transverse Mercator. The georeferenced data were inserted in the TerraView 3.1.3 application in order to prepare the figures. 


\section{Results}

The prevalence found in the present study was $51.1 \%(163 / 319$; C.I. $45.5 \%$ - 56.7\%). At least one infected animal was found on all $(100.0 \%)$ of the properties (24/24). Prevalence rates ranged from $20.0 \%$ to $100.0 \%$ on the family farms evaluated (Figure 2).

Figure 2. Distribution (by property) of the prevalence of bovine viral diarrhea infection on family farms in the Brejo microregion of Pernambuco.

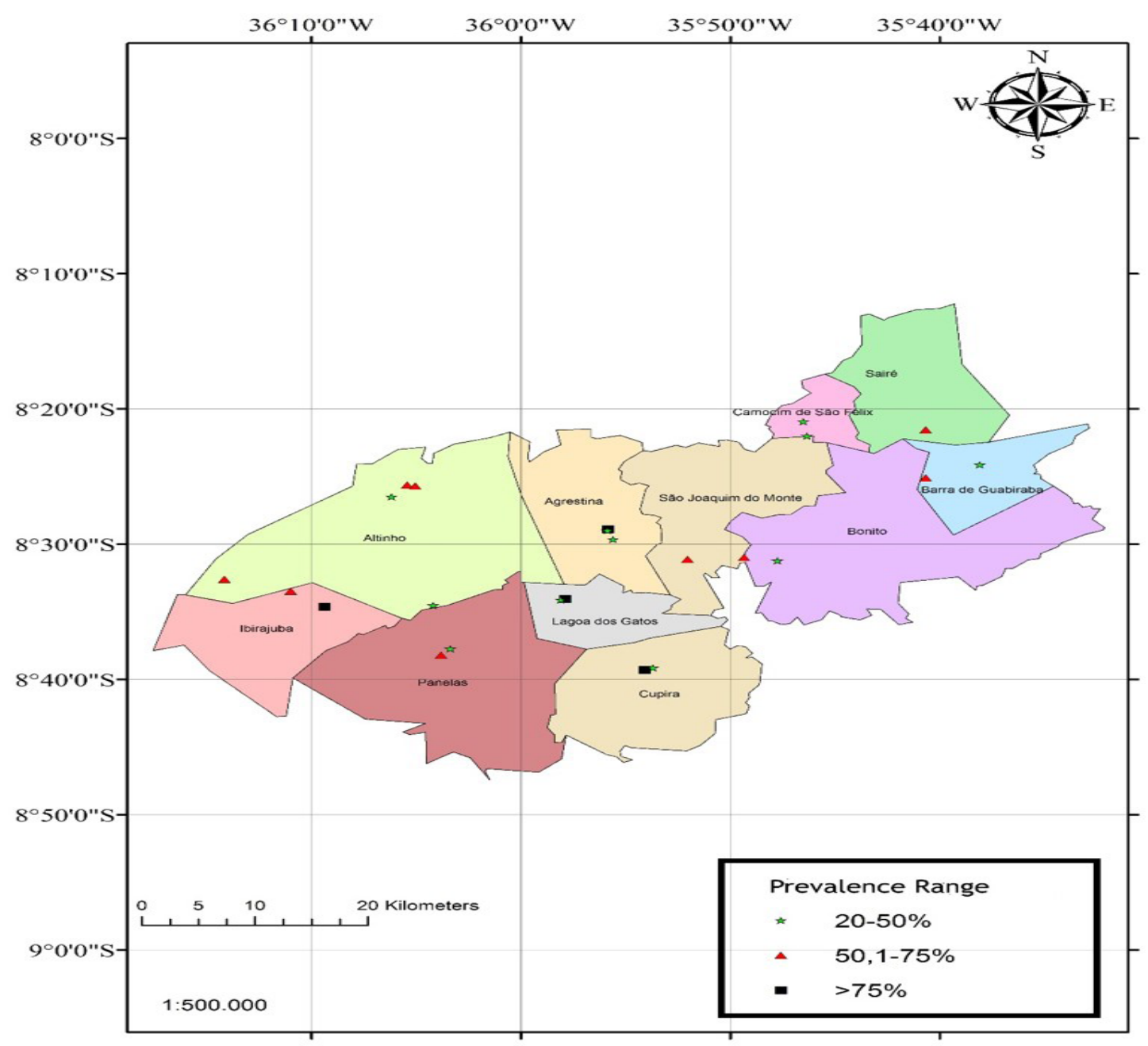

The distribution of prevalence by county ranged a variation from $\log 101.0$ to $\log 103.1$, as seen in from $23.1 \%$ to $70.0 \%$, as shown in Table 1 . With Table 2 . As for risk factors, the variables studied regards to the antibody titers in the serum, there was herein are displayed in Table 3. 
Table 1. Prevalence (\%) of anti-BVDV antibodies by district in the Brejo microregion of Pernambuco from September 2013 to February 2014.

\begin{tabular}{lcc}
\hline \multicolumn{1}{c}{ District } & $\mathrm{N}$ & Seroneutralization Positive \\
\hline Agrestina & 47 & $23(48.9 \%)$ \\
Altinho & 91 & $47(51.6 \%)$ \\
Barra de Guabiraba & 30 & $16(53.3 \%)$ \\
Bonito & 15 & $6(40.0 \%)$ \\
Camocim de São Félix & 26 & $6(23.1 \%)$ \\
Cupira & 19 & $11(57.9 \%)$ \\
Ibirajuba & 20 & $14(70.0 \%)$ \\
Lagoa dos Gatos & 29 & $17(58.6 \%)$ \\
Panelas & 23 & $11(47.8 \%)$ \\
Sairé & 9 & $6(66.7 \%)$ \\
São Joaquim do Monte & 10 & $6(60.0 \%)$ \\
\hline
\end{tabular}

Convention: $\mathrm{N}$ - Total animals by district.

Table 2. Frequency of antibody titers against BVDV in herds from family farms in the Brejo microregion of Pernambuco from September 2013 to February 2014.

\begin{tabular}{lcc}
\hline Titration $\left(\right.$ expressed as $\left.\log _{10}\right)$ & A.F. & R.F. $(\%)$ \\
\hline $1 \leq 1,3$ & 60 & 36.8 \\
$1,4 \leq 1,6$ & 36 & 22.1 \\
$1,7 \leq 1,9$ & 32 & 19.6 \\
$2,0 \leq 2,2$ & 15 & 9.2 \\
$2,3 \leq 2,5$ & 6 & 3.7 \\
$2,6 \leq 2,8$ & 13 & 8.0 \\
$\geq 3,1$ & 1 & 0.6 \\
\hline Total & 163 & 100.0 \\
\hline
\end{tabular}

Convention: A.F. - Absolute Frequency; R.F. - Relative Frequency.

Table 3. Univariate analysis of risk factors associated with infection by bovine viral diarrhea in herds from family farms in the Brejo microregion of Pernambuco from September 2013 to February 2014.

Continue ...

\begin{tabular}{lccc}
\hline Variables & $\mathrm{N}$ & $\mathrm{SN}$ & P value \\
\hline Breeding system & & & \\
Extensive & 20 & $11(55.0 \%)$ & 0.449 \\
Semi-intensive & 299 & $152(50.8 \%)$ & \\
Feeding & & & \\
$\quad$ Pasture & 37 & $17(45.9 \%)$ & 0.311 \\
$\quad$ Ration + Pasture & 282 & $146(51.8 \%)$ & \\
Provides colostrum & & & \\
$\quad$ Yes & 300 & $148(49.3 \%)$ & $0.012^{*}$ \\
$\quad$ No & 19 & $15(78.9 \%)$ & \\
Consortium breeding & & & \\
\hline
\end{tabular}


...Continuation

\begin{tabular}{|c|c|c|c|}
\hline Yes & 182 & $104(57.1 \%)$ & \multirow{2}{*}{$0.012 *$} \\
\hline No & 137 & $59(43.1 \%)$ & \\
\hline \multicolumn{4}{|l|}{ Presence of wild animals } \\
\hline Yes & 41 & $18(43.9 \%)$ & \multirow{2}{*}{0.206} \\
\hline No & 278 & $145(52.2 \%)$ & \\
\hline \multicolumn{4}{|l|}{ Origin of animals } \\
\hline Breeders from the region & 128 & $64(50.0 \%)$ & \multirow{3}{*}{0.909} \\
\hline Breeders recommendations & 58 & $31(53.4 \%)$ & \\
\hline Fair/exhibition & 133 & $68(51.1 \%)$ & \\
\hline \multicolumn{4}{|l|}{ The premises are cleaned } \\
\hline Yes & 65 & $39(60.0 \%)$ & \multirow{2}{*}{0.070} \\
\hline No & 254 & $124(42.8 \%)$ & \\
\hline \multicolumn{4}{|l|}{ Coverage } \\
\hline Natural mating & 300 & $152(50.7 \%)$ & \multirow{2}{*}{0.354} \\
\hline Insemination & 19 & $11(57.9 \%)$ & \\
\hline \multicolumn{4}{|l|}{ The bull is owned ${ }^{\mathrm{a}}$} \\
\hline Yes & 280 & $144(51.4 \%)$ & \multirow{2}{*}{0.324} \\
\hline No & 20 & $8(40.0 \%)$ & \\
\hline \multicolumn{4}{|l|}{ Technical assistance } \\
\hline Yes & 35 & $14(40.0 \%)$ & \multirow{2}{*}{0.112} \\
\hline No & 284 & $149(52.5 \%)$ & \\
\hline \multicolumn{4}{|l|}{ The disease is known } \\
\hline Yes & 61 & $20(32.8 \%)$ & \multirow{2}{*}{$0.001 *$} \\
\hline No & 258 & $143(55.4 \%)$ & \\
\hline
\end{tabular}

Conventions: N - Total animals; SN - seroneutralization; *Significant associations to level 5\%; OR - odds ratio; C.I. - Confidence interval; abase used -300 .

According to the logistic regression analysis, $\mathrm{p}=0.018)$; disease unknown (OR 2.54; $\mathrm{p}=0.001)$ the variables identified as risk factors were as and consortium breeding (OR 1.76; p=0.013) follows: not providing colostrum (OR 3.85; (Table 4).

Table 4. Logistic regression of the risk factors associated with infection by bovine viral diarrhea in herds from family farms in the Brejo microregion of Pernambuco from September 2013 to February 2014.

\begin{tabular}{lccc}
\hline Variables & P value & OR $^{\mathrm{a}}$ & ${\text { CI } 95 \%{ }^{\mathrm{b}}}^{\text {Colostrum not provided }}$ \\
\hline Disease unknown & 0.018 & 3.85 & $1.24-11.87$ \\
Consortium breeding & 0.001 & 2.54 & $1.41-4.59$ \\
\hline
\end{tabular}

${ }^{a}$ Odds ratio, b Confidence Interval of $95 \%$.

A number of clinical signs, such as reduced milk in the investigative questionnaire, but without production $(\mathrm{p}=0.182)$, mastitis cases $(\mathrm{p}=0.437)$ and significant results. reproductive problems $(\mathrm{p}=0.110)$, were included 


\section{Discussion}

The prevalence found in this study $(51.1 \%)$ is considered high and is in agreement with results previously found in Brazil and in other countries. A study conducted in Belgium reported 44.4\% seropositivity (SARRAZIN et al., 2013), while another study in Turkey reported a prevalence of $58.2 \%$ (GÜR, 2011). A prevalence of 59.9\% was reported by Carbonero et al. (2011) in Argentina. In Brazil, similar results were observed in other states: $58.3 \%$ in Santa Catarina (FINO et al., 2013); 54.1\% in Goiás (GUIMARÃES et al., 2001); 56.5\% in São Paulo (SAMARA et al., 2004) and $57.7 \%$ in Rio Grande do Sul (FRANDOLOSO et al., 2008). In the northeast of the country, similar results $(56.0 \%)$ were found in Bahia (NORONHA et al., 2003). In Pernambuco, Castro et al. (1993) found $72.6 \%$ seropositivity, which is higher than that found in the present study. The difference in the results found in the present study and in the study conducted by Castro et al. (1993) in Pernambuco could be related to the type of sample design and differences in the hygienic and sanitary management procedures used on the properties.

It was notable in the present study that BVDV infection is widespread in herds on family farms in the microregion studied herein, with similarities to results found in previous studies (GUIMARÃES et al., 2001; NORONHA et al., 2003; SAMARA et al., 2004; FRANDOLOSO et al., 2008; CARBONERO et al., 2011; GÜR, 2011; FINO et al., 2013; SARRAZIN et al., 2013). This indicates that the sanitary variables of prevention and control of the BVDV are similar in the herds studied herein. Performing quarantine procedures, vaccinations and tests on herds and new acquisitions could lead to the identification and removal of persistently infected animals (PI), thereby minimizing the spread of the virus.

The high number of herds that had at least one reagent animal $(100.0 \%)$ is similar to the results reported by Fino et al. (2013) in the state of Santa
Catarina and compatible with the $82.4 \%$ found in Rio Grande do Sul (QUINCOZES et al., 2007) and with the $97.6 \%$ found in the state of Maranhão (CHAVES et al., 2012). These results could be associated with inadequate procedures of sanitary management on the family farms in question, resulting in the introduction of viremic cattle (acute infection or PI). This in turn favors the spread and maintenance of the BVDV, as noted by Samara et al. (2004).

As for the frequency of antibodies found in the present study, the majority of seropositive animals (58.9\%) exhibited titration levels between $1 \leq 1.6$, while the lowest rate was observed in the range $\geq 3.1$ $(0.6 \%)$. These results indicate natural infection, given that the age of the animals examined was above 6 months and they had no history of vaccination, thus ruling out the possibility of passive immunity (colostrum) and active immunity induced by the vaccine.

The results of the present study demonstrate that the animals had, or have, direct contact with sources of BVDV infection (bovines with acute infection or PI). Herds with a high prevalence probably contain at least one PI animal. Therefore, prior to detecting the presence of PI animals in herds, it is important to determine the prevalence of animals with antibodies to BVDV. Bedeković et al. (2013) reported a similar prevalence rate to that found in the present study (100.0\%) and found that $20.0 \%$ of the herds exhibited the presence of PI animals. The increased prevalence of infection is directly proportional to the percentage of PI animals in the herd (RIBEIRO; PEREIRA, 2004). PI animals exhibit immunotolerance to the homologous strain of the virus, but may be immunocompetent relative to other strains, unlike induced tolerance. In these cases, the PI animal may be positive for the virus (direct testing of the agent by PCR or ELISA antigen) and the reagent in the seroneutralization test for the heterologous strain (antibodies) (DEZEN et al., 2013). Further studies should be conducted in this region to identify PI animals and to determine 
the percentage of these animals in herds, given that they act as potential sources of infection.

Of the identified risk factors, not providing colostrum exhibited an OR value of $3.85(p=0,018)$ in the logistic regression analysis. This result shows that animals that do not receive colostrum at birth are 3.85 times more likely to be infected by the BVDV than those that receive colostrum. The risk factor in question may be associated with decreased immunity among animals that did not receive maternal antibodies via colostrum and, thereby, increase the chances of becoming infected with infectious agents, especially in the first days of life (KORHONEN et al., 2000). Likewise, a deficiency in the passage of passive immunity soon after birth influences the health status of calves and, consequently, the development of the animals and the morbidity and mortality rates related to various infectious agents (WINDEYER et al., 2014).

The practice of consortium breeding was significant in the logistic regression (OR 1.76; $\mathrm{p}=0.013$ ). This could be due to the fact that other farm animals act as reservoirs. The presence of heterologous species in breeding systems can influence the serological diagnosis, given that some species are susceptible to pestiviruses (PASSLER; WALZ, 2009). Quincozes et al. (2007) observed that the presence of sheep in consortium breeding systems has been considered a risk factor for the presence of anti-BVDV antibodies. Meanwhile, Chaves et al. (2012) reported that pig breeding is a statistically significant risk factor for BVDV seropositivity.

With regards to knowledge of the BVDV, approximately $81.0 \%(19 / 24)$ of family producers have not received any guidance related to the BVDV. Thus, the variable "disease unknown" proved to be a risk factor in the logistic regression (OR 2.54; $\mathrm{p}=0.001$ ). When the owner of a herd is unaware of the BVDV, the herd is 2.54 times more likely to acquire the infection than herds whose owner has some knowledge of the disease.
The high prevalence of the BVDV, together with a lack of knowledge about the disease, can increase the level of infection in herds (SAMARA et al., 2004). A deficiency of information about the BVDV may be associated with a failure or lack of technical assistance. Information about the BVDV and herd health status are extremely important for the adoption of more efficient controls on the property. Sanitary measures, based on risk factors are the basis for effective sanitary management (NISKANEN; LINDBERG, 2003). The adoption of specific measures, such as the disinfection of veterinary instruments (FODDAI et al., 2014), vaccination (RIBEIRO; PEREIRA, 2004; DEZEN et al., 2013), the identification and elimination of PI animals (RIBEIRO; PEREIRA, 2004) and laboratory examinations for replacement animals (SMITH et al., 2014) are indicated as effective measures to control BVDV infection. Coupled with increased knowledge of the disease, the adoption of such measures could lead to improved production efficiency and increased economic profitability.

\section{Conclusions}

Based on the results obtained it is possible to conclude that BVDV infection is widespread among herds on family farms in the microregion studied herein. Health education policies must be implemented both for producers and for the professionals who provide technical assistance. There is no doubt that better hygienic and sanitary measures, based on the risk factors identified in the present study should be implemented in order to reduce the prevalence of the BVDV.

\section{Conflict of Interest Statement}

The authors of this article have no financial or personal relationship to influence improperly or interfere with the article content. 


\section{Acknowledgements}

The authors would like to thank the Biological Institute of São Paulo for processing the samples and the Agronomic Institute of Pernambuco for its support and confidence in the work.

\section{References}

ASMARE, K.; REGASSA, F.; ROBERTSON, L. J.; MARTIN, A. D.; SKJERVE, E. Reproductive disorders in relation Neospora caninum, Brucella spp. and bovine viral diarrhoea virus sero status in breeding and dairy farms of central and southern Ethiopia. Epidemiology \& Infection, Cambridge, v. 141, n. 8, p. 1772-1780, 2013.

BEDEKOVIĆ, T.; LEMO, N.; BARBIĆ, L.; CVETNIĆ, Z.; LOJKIĆ, I.; BENIĆ, M.; ČAČ, Z.; LOJKIĆ, M.; MADIĆ, J. Influence of category, herd size, grazing and management on epidemiology of bovine viral diarrhoea in dairy herds. Acta Veterinary Brno, República Checa, v. 82, n. 2, p. 125-130, 2013.

BRASIL. Departament of Agriculture, Livestock and Supply. Brasília: MAPA, 2014. Disponível em: <http:// www.agricultura.gov.br>. Acesso em: 20 jul. 2014.

CARBONERO, A.; MALDONADO, A.; PEREA, A.; GARCÍA-BOCANEGRA, I.; BORGE, C.; TORRALBO, A.; ARENAS-MONTES, A.; ARENAS-CASAS, A. Factores de riesgo del síndrome respiratório bovino em terneros lactantes de Argentina. Archivos de Zootecnia, Córdoba, v. 60, n. 229, p. 41-51, 2011.

CASTRO, R. S.; MELO, L. E. H.; ABREU, S. R. A.; MUNIZ, A. M. M.; ALBUQUERQUE, A. P. S. Anticorpos neutralizantes contra pestivírus em soros bovinos do Estado de Pernambuco. Pesquisa Agropecuária Brasileira, Rio de Janeiro, v. 28, n. 11, p. 1327-1331, 1993.

CÔRTES, J. A. Epidemiologia: conceitos e principais fundamentos. São Paulo: Varela, 1993. 44 p.

CHAVES, N. P.; BEZERRA, V. E.; SOUSA, V. E.; SANTOS, H. P.; PEREIRA, H. M. Frequência e fatores associados à infecção pelo vírus da diarreia viral bovina em bovinos leiteiros não vacinados no estado do Maranhão. Arquivo do Instituto Biológico, São Paulo, v. 79, n. 4, p. 495-502, 2012.

DEZEN, S.; OTONEL,A.A.;ALFIERI,A. F.; LUNARDI, M.; ALFIERI, A. A. Perfil da infecção pelo vírus da diarreia viral bovina (BVDV) em um rebanho bovino leiteiro de alta produção e com programa de vacinação contra BVDV. Pesquisa Veterinária Brasileira, Rio de Janeiro, v. 33, n. 2, p. 141-147, 2013.
DIAS, F. C.; SAMARA, S. I. Detecção de anticorpos contra o vírus da diarreia viral bovina no soro sanguíneo, no leite individual e no leite de conjunto em tanque de expansão de rebanhos não vacinados. Brazilian Journal of Veterinary Research and Animal Science, São Paulo, v. 40, n. 3, p. 161-168, 2003.

Aspectos relevantes da infecção pelo vírus da diarreia viral bovina (BVDV). Instituto Biológico, São Paulo, v. 72, n. 1, p. 1-9, 2010.

FLORES, E. F.; WEIBLEN, R.; VOGEL, F. S. F.; ROEHE, P. M.; ALFIERI, A. A.; PITUCO, E. M. Infecção pelo vírus da Diarreia Viral Bovina (BVDV) no Brasil: histórico, situação atual e perspectivas. Pesquisa Veterinária Brasileira, Rio de Janeiro, v. 25, n. 3, p. 125 134, 2005.

FINO, T. C. M.; MELO, C. B.; RAMOS, A. F.; MCMANUS, C.; LEITE, R. C.; MARTINS, E. Ocorrence of antibodies against bovine herpesvirus 1 and bovine viral diarrhoea virus in crioula lageana cattle. Journal of Animal Science Advances, Shabestar, v. 3, n. 4, p. 165170, 2013.

FODDAI, A.; BOKLUND, A.; STOCKMARR, A.; KROGH, K.; ENOE, C. Quantitative assessment of the risk of introduction of bovine viral diarrhea virus in Danish dairy herds. Preventive Veterinary Medicine, Amsterdam, v. 116, n. 1-2, p. 75-88, 2014.

FRANDOLOSO, R.; ANZILIERO, D.; SPAGNOLO, J.; KUSE, N.; FIORI, C.; SCORTEGAGNA, T.; BARCELLOS, L. J. G.; KREUTZ, C. Prevalência de leucose enzoótica bovina, diarreia viral bovina, rinotraqueíte infecciosa bovina e neospora bovina em 26 propriedades leiteiras da região nordeste do Rio Grande do Sul, Brasil. Ciência Animal Brasileira, Goiânia, v. 9, n. 4, p. 1102-1106, 2008.

GUARINO, H.; NÚÑES, A.; REPISO, M. V.; GIL, A.; DARGATZ, D. A. Prevalence of serum antibodies to bovine herpesvirus-1 and bovine viral diarrhea virus in beef cattle in Uruguay. Preventive Veterinary Medicine, Amsterdam, v. 85, n. 1-2, p. 34-40, 2008.

GUIMARÃES, P. L. S. N.; CHAVES, N. S. T.; SILVA, L. A. F.; ACYPRESTE, C. S. Frequência de anticorpos contra o vírus da diarreia viral bovina em bovinos, em regime de criação semi-extensivo. Ciência Animal Brasileira, Gioânia, v. 2, n. 1, p. 35-40, 2001.

GÜR, S. Prevalence of bovine viral diarrhoea, bovine herpesvirus type 1 and 4 infections in repeat breeding cows in Western Turkey. Brazilian Journal of Veterinary Research and Animal Science, São Paulo, v. 48, n. 3, p. 228-233, 2011. 
HERRERA, A. R.; MANCHEGO, A. S.; RAMÍREZ, M. V.; MORE, J. B.; RIVERA, H .G. Seroprevalencia del virus de la diarreia viral em bovinos de crianza extensiva de la provincia de San Pablo, Cajamarca. Revista Investigaciones Veterinarias del Perú, Lima, v. 22, n. 2 , p. 171-175, 2011.

HOSMER, D. W.; LEMESHOW, S. Applied logistic regression. New York: John Wiley \& Sons, 1989. 241 p.

INSTITUTO BRASILEIRO DE GEOGRAFIA E ESTATÍSTICA - IBGE. Brazilian institute of geography and statistics. Censo agropecuário 2006: Agricultura familiar. Rio de Janeiro: IBGE, 2006a. 267 p.

. Rio de Janeiro: IBGE, 2006b. Disponível em: <http://www.ibge.gov.br006>. Acesso em: 19 jul. 2014.

KORHONEN, H.; MARNILA, P.; GILL, H. S. Bovine milk antibodies for health. The British Journal of Nutrition, Cambridge, v. 84, n. 1, p. 135-146, 2000.

NISKANEN, R.; LINDBERG, A. Transmission of bovine viral diarrhoea virus by unhygienic vaccination procedures, ambient air, and from contaminated pens. The Veterinary Journal, London, v. 165, n. 2, p. 125-130, 2003.

NORONHA, R. P.; CAMPOS, G. S.; SARDI, S. I. Pesquisa do vírus da diarreia viral bovina em bovinos jovens. Brazilian Journal of Veterinary Research and Animal Science, São Paulo, v. 40, n. 6, p. 424-430, 2003.

PASSLER, T.; WALZ, P. H. Bovine viral diarrhea virus infections in heterologous species. Animal Health Research Reviews, Cambridge, v. 11, n. 2, p. 191-205, 2009.

QUINCOZES, C. G.; FISCHER, G.; HÜBNER, S. O.; VARGAS, G. A.; VIDOR, T.; BROD, C. S. Prevalência e fatores associados à infecção pelo vírus da diarreia viral bovina na região Sul do Rio Grande do Sul. Semina: Ciências Agrárias, Londrina, v. 28, n. 2, p. 269-276, 2007.

REED, L. J.; MUENCH, H. A simple method of estimating fifty per cent endpoints. American Journal of Epidemiology, Baltimore, v. 27, n. 3, p. 493-497, 1938.
RIBEIRO, J. N.; PEREIRA, A. Aspectos da epidemiologia da infecção e persistência do vírus da diarreia viral bovina em explorações de bovinos leiteiros. Revista Portuguesa de Ciências Veterinárias, Lisboa, v. 99, n. 549, p. 41-51, 2004.

SAMARA, S. I.; DIAS, F. C.; MOREIRA, S. P. G. Ocorrência da diarreia viral bovina nas regiões sul do Estado de Minas Gerais e nordeste do Estado de São Paulo. Brazilian Journal of Veterinary Research and Animal Science, São Paulo, v. 41, n. 6, p. 396-403, 2004.

SARRAZIN, S.; VELDHUIS, A.; MÉROC, E.; VANGEEL, I.; LAUREYNS, J.; DEWULF, J.; CAIJ, A. B.; PIEPERS, S.; HOOYBERGHS, J.; RIBBENS, S.; STEDE, Y. V. D. Serological and virological BVDV prevalence and risk factor analysis for herds to be BVDV seropositive in Belgian cattle herds. Preventive Veterinary Medicine, Amsterdam, v. 108, n. 1, p. 28-37, 2013.

SMITH, R. L.; SANDERSON, M. W.; JONES, R.; N'GUESSAN, Y.; RENTER, D.; LARSON, R.; WHITE, B. J. Economic risk analysis model for bovine viral diarrhea virus biosecurity in cow-calf herds. Preventive Veterinary Medicine, Amsterdam, v. 113, n. 4, p. 492503, 2014.

THOMPSON, J. A.; LEITE, R. M. H.; GONÇALVES, V. S. P.; LEITE, R. C.; BANDEIRA, D. A.; HERRMANN, G. P.; MOREIRA, E. C.; PRADO, P. E. F.; LOBATO, Z. I. P.; BRITO, C. P. T.; LAGE, A. P. Spatial hierarchical variances and age covariances for seroprevalence to Leptospira interrogans serovar hardjo, BoHV-1 and BVDV for cattle in State of Paraíba, Brazil. Preventive Veterinary Medicine, Amsterdam, v. 76, n. 3-4, p. 290-301, 2006.

THRUSFIELD, M.V. Epidemiologia veterinária. 2. ed. São Paulo: Roca, 2004. 556 p.

WINDEYER, M. C.; LESLIE, K. E.; GODDEN, S. M.; HODGINS, D. C.; LISSEMORE, K. D.; LEBLANC, S. J. Factors associated with morbidity, mortality, and growth of dairy heifer calves up to 3 months of age. Preventive Veterinary Medicine, Amsterdam, v. 113, n. 2, p. 231-240, 2014.

WORLD ORGANIZATION FOR ANIMAL HEALTH - OIE. Manual of diagnostic tests and vaccines for terrestrial animals. 7. ed. France: OIE, 2012. 1404 p. 
